\title{
Net nutrient absorption and liver metabolism in lactating dairy cows fed supplemental dietary biotin
}

\author{
C. K. Reynolds ${ }^{1 \dagger}$, D. E. Beever ${ }^{1 \neq}$, W. Steinberg ${ }^{2}$ and A. J. Packington ${ }^{3}$
}

${ }^{1}$ School of Agriculture, Policy and Development, The University or Reading, PO Box 237, Earley Gate, Reading, RG6 6AR, UK; ${ }^{2}$ DSM Nutritional Products France, NRD/CA, PO Box 170, F-68305, SAINT LOUIS, Cedex, France; ${ }^{3}$ DSM Nutritional Products UK Ltd., Deles Road, Heanor Gate, Heanor, Derbyshire, DE75 7SG, UK

(Received 6 June 2006; Accepted 4 December 2006)

\begin{abstract}
The effect of feeding supplemental biotin on net absorption and metabolism of nutrients by the portal-drained viscera (PDV; the gut, pancreas, spleen and associated fat) and liver of lactating dairy cows was measured. Three cows in early to mid-lactation catheterised for measurements of net nutrient absorption and metabolism by the PDV and liver were fed a total-mixed ration with or without supplemental biotin at $20 \mathrm{mg} /$ day using a switch-back design ( $A B A$ v. BAB) with three 2-week periods. There were no effects of feeding biotin on dry matter intake $(22.2 \mathrm{~kg} /$ day), milk yield $(29.5 \mathrm{~kg} /$ day) or milk composition. There was also no effect of feeding biotin on net release of glucose by the liver, net liver removal of glucose precursors (propionate, alanine, lactate) or net liver release of $\beta$-hydroxybutyrate. Feeding biotin increased net PDV release of ammonia. Reasons for the response are not certain, but a numerical increase in net PDV release of acetate suggests that rumen or hindgut fermentation was altered. Results of the present study do not support the hypothesis that supplemental biotin increases liver glucose production in lactating dairy cows.
\end{abstract}

Keywords: biotin, dairy cows, lactation, liver, portal-drained viscera

\section{Introduction}

Biotin is synthesised by rumen micro-organisms and thus has not been considered an essential ingredient in ruminant diets. Textbooks state unequivocally that the 'evidence indicates that supplementary feeding (of B-complex vitamins) is of little value unless some unusual condition prevails' (Church, 1979). This view has now been challenged as regards to the potential benefit of supplemental B-complex vitamins in lactating dairy cows (Girard, 1998). It is well documented that long-term biotin supplementation can have positive effects on hoof health in pigs (Webb et al., 1984) and horses (Comben et al., 1984). More recently, studies in lactating dairy cows have consistently demonstrated a positive effect of supplemental biotin on hoof growth, integrity, and the incidence of lameness (Midla et al., 1998; Fitzgerald et al., 2000; Hedges et al., 2001; Bergsten et al., 2003). In some of these studies (Midla et al., 1998; Bergsten et al., 2003) and others (Bonomi et al., 1996; Zimmerly and Weiss, 2001; Majee et al., 2003), supplemental biotin also increased milk yield,

\footnotetext{
† E-mail: c.k.reynolds@reading.ac.uk

${ }^{\ddagger}$ Present address: R Keenan \& Co, Borris, Co. Carlow, Ireland
}

although the effect was not consistent across all studies (Fitzgerald et al., 2000; Rosendo et al., 2004). Although improved hoof health would ultimately benefit both drymatter intake and milk yield, the response in milk yield to supplemental biotin is more rapid than improvements in hoof integrity, and can occur without changes in DMI (Zimmerly and Weiss, 2001), suggesting a metabolic effect.

Ruminants normally absorb little glucose from the small intestine, thus glucose requirements are met primarily by liver production (Reynolds, 1995). Biotin is a cofactor for two carboxylase enzymes required for glucose synthesis in the liver, pyruvate carboxylase and propionyl-CoA carboxylase. In nonruminants, biotin deficiency has been associated with an inhibition of gluconeogenesis and reduced blood glucose levels (Bender, 1999). The effect of supplemental biotin on milk yield has been attributed to an effect on rumen fermentation and digestion, glucose production in the liver, or metabolic effects on nutrient partitioning and milk synthesis (Zimmerly and Weiss, 2001). The objective of the present study was to determine the effect of supplemental biotin on net absorption and liver metabolism of glucose, glucose precursors and other products of digestion and gut metabolism. 
Reynolds, Beever, Steinberg and Packington

\section{Material and methods}

\section{Animals}

Three Holstein $\times$ Friesian cows in their third, fourth or fifth lactation were used. Cows were 36,71 or 174 days post partum and $670 \pm 9 \mathrm{~kg}$ body weight at the beginning of the first experimental period. At the end of the study they averaged $661 \pm 9 \mathrm{~kg}$ body weight. Cows were surgically prepared with a rumen fistula and catheters for measurement of net absorption and metabolism of nutrients by the portal-drained viscera (PDV: the tissues of the gastrointestinal tract, pancreas, spleen and associated fat) and liver as described by Huntington et al. (1989). Surgeries were conducted from 25 to 31 months prior to the beginning of the present study; therefore, cows had completed two entire lactations and a number of previous studies of nutrient metabolism (Reynolds et al., 1998, 1999 and 2000; Benson et al., 2002) between surgery and the present study. Cows were housed, fed and milked in individual standings employing head halters or neck yokes allowing continuous access to water and trace mineralised salt blocks. Cows were milked twice daily at 0600 and $1700 \mathrm{~h}$, weighed weekly and allowed grazing when not on experiment. All procedures used were licensed under the Animal Scientific Procedures Act (1986) and cows were under the routine care and inspection of a herd veterinarian and a Home Office Veterinary inspector.

\section{Diets}

Cows were fed a basal total-mixed ration containing 300 , 200 , and $500 \mathrm{~g}$ per $\mathrm{kg}$ dry matter (DM) of dehydrated lucerne, grass silage, and cereal-based concentrates (Table 1), respectively. Based on the measured chemical composition of ingredients (Table 2) the total mixed ration DM fed averaged $178 \mathrm{~g}$ crude protein, $158 \mathrm{~g}$ starch, $369 \mathrm{~g}$ neutral-detergent fibre and $232 \mathrm{~g}$ acid-detergent fibre per $\mathrm{kg}$ DM. Daily rations were fed as 24 equal meals provided hourly to minimise post-prandial fluctuations in nutrient absorption and metabolism. Refusals were removed at $0730 \mathrm{~h}$ and feeding of a day's ration began at $0800 \mathrm{~h}$.

Table 1 Formulation of the total mixed ration fed

\begin{tabular}{lr}
\hline \hline Ingredient & $\mathrm{g} / \mathrm{kg} \mathrm{DM}$ \\
\hline Dehydrated, chopped lucerne ${ }^{1}$ & 300.0 \\
Grass silage & 200.0 \\
Wheat feed (mids) & 191.7 \\
Ground barley & 142.9 \\
Ground maize & 47.8 \\
Molassed sugar-beet shreds & 47.8 \\
Soya-bean meal, solvent extracted, 48\% CP & 52.7 \\
Sodium bicarbonate & 4.9 \\
High phosphorus mineral mix & 12.2 \\
\hline
\end{tabular}

' 'Hippoluz', Dengie Crops Ltd., Southminster, UK.

${ }^{2}$ Labelled as containing $180 \mathrm{~g}$ calcium (as dicalcium phosphate and limestone), $120 \mathrm{~g}$ phosphorus (as dicalcium phosphate), $50 \mathrm{~g}$ magnesium (as magnesium oxide and magnesium phosphate), $1.5 \mathrm{~g}$ copper (as copper sulphate), $0.015 \mathrm{~g}$ selenium (as sodium selenite), $380000 \mathrm{IU}$ vitamin A, $80000 \mathrm{IU}$ vitamin D3, $550 \mathrm{IU}$ vitamin E per $\mathrm{kg}$.
Table 2 Composition ( $\mathrm{g} / \mathrm{kg}$ dry matter) of the forages and concentrate mixture fed

\begin{tabular}{lccc}
\hline \hline Component & Grass silage & Lucerne & Concentrates \\
\hline Nitrogen & 25.8 & 26.4 & 30.8 \\
Starch & $\mathrm{ND}^{\dagger}$ & $\mathrm{ND}$ & 316.7 \\
Neutral-detergent fibre & 485.1 & 491.7 & 248.7 \\
Acid-detergent fibre & 315.9 & 402.2 & 95.5 \\
Ash & 83.0 & 108.0 & 74.9 \\
\hline \hline
\end{tabular}

${ }^{\dagger}$ Not determined.

\section{Treatments}

Cows were fed $20 \mathrm{mg}$ supplemental biotin daily in $500 \mathrm{~g}$ ground wheat or $500 \mathrm{~g}$ ground wheat as a control in a switch-back design with three 2-week periods (ABA v. $B A B)$. Two cows received the control treatment in the first period, and one received the biotin treatment first. The control wheat carrier used was derived from the same batch used as the carrier for the biotin. To reduce the risk of mistakes in feeding supplements the biotin supplement included trace amounts of $\mathrm{CrO}_{3}$ to impart a green colour. Supplements were added to the total mixed ration daily and for the duration of the study basal ration DM offered was held at $97 \%$ of ad libitum intake for the week immediately preceding the first period of the study. This was to ensure complete consumption of the biotin supplement and minimise variation in liver and PDV metabolism due to changes in intake.

\section{Measurements}

Milk yield and DM intake were measured daily throughout the study. During the last week of each period forage and concentrate samples were obtained daily, analysed for DM content and then composited, dried at $60^{\circ} \mathrm{C}$, ground and analysed for chemical composition by a commercial laboratory (Natural Resources Management, Ltd., Bracknell, UK). Any refusals were weighed and analysed for DM content. Milk samples were obtained over the last 7 days of each period, treated with preservative $(1 \mathrm{mg} / \mathrm{ml}$ potassium dichromate; Lactabs, Thompson and Capper, Runcorn, UK) and stored at $4{ }^{\circ} \mathrm{C}$ until analysed for crude protein, fat and lactose content by infrared spectroscopy (Foss Electric, Ltd, UK).

Measurements of blood flow and net nutrient metabolism by the PDV, liver and total-splanchnic (PDV plus liver) tissues were obtained on the last day of each period using methods described previously (Huntington et al., 1989; Reynolds et al., 2003). Eight simultaneous blood sample sets $(20 \mathrm{ml})$ from the mesenteric artery and portal and hepatic veins were obtained hourly beginning at 0730 hours during continuous mesenteric vein infusion of sterile $\rho$-aminohippurate (PAH; a marker for blood flow measurements) solution. Anaerobic blood samples $(2 \mathrm{ml})$ were also obtained for immediate analysis of $\mathrm{pO}_{2}, \mathrm{pCO}_{2}$ and $\mathrm{pH}$ (Reynolds et al., 2003). Blood samples were immediately placed on ice and kept chilled until processed, analysed or frozen. Plasma concentrations of PAH, glucose, and 
L-lactate were obtained as soon as possible using assays adapted for use on a discrete analyser (Cobas-MIRA, Roche, Welwyn Garden City, UK) as described (Reynolds et al., 2003). Fresh blood samples were analysed for packed cell volume by micro-centrifugation and haemoglobin using a colorimetric assay and blood $\mathrm{O}_{2}$ and $\mathrm{CO}_{2}$ content calculated as described by Reynolds et al. (2003). Blood sample aliquots were pooled by sample site for each cow observation $(n=9)$, deproteinised, neutralised, and stored frozen in aliquots at $-85^{\circ} \mathrm{C}$ until assayed for concentrations of ammonia, L-alanine, L-glutamate, L-glutamine and $\mathrm{B}-\mathrm{OH}$-butyrate as described by Reynolds et al. (2003). Additional pools of blood samples were analysed for volatile fatty acid (VFA) concentrations as described by Reynolds et al. (2003).

\section{Calculations}

Blood and plasma flow for the portal vein and liver and calculations of net PDV, liver and total splanchnic (PDV plus liver) flux of nutrients and blood gasses were calculated as described (Reynolds et al., 2003). Using venousarterial differences, a negative flux denotes net removal of a metabolite from blood supply, whilst a positive flux denotes net release of a metabolite into venous blood. Net flux rates represent the sum of unidirectional uptake and release and therefore may underestimate unidirectional uptake and release for many metabolites when tissues as heterogenous as the PDV and liver are concerned. Net liver extraction as a percentage of total supply and net PDV release were also calculated (Reynolds et al., 2003).

\section{Statistical analysis}

There were no missing blood samples. Averages for each cow-sampling period were statistically analysed using the mixed procedure of Statistical Analysis Systems Institute (2006) and a model testing fixed effects of period and treatment and random effects of cow and the cow by period interaction as described by Templeman (2004). Data are presented as least squares means with the standard error of the control mean. Because the number of observations is small, $P<0.10$ is considered significant.

\section{Results}

There was no effect of biotin supplementation on body weight, DMI, milk yield or milk composition (Table 3). Blood and plasma flow and packed cell volume were also unaffected by biotin (Table 4). Similarly, arterial concentrations of most metabolites (Table 4) were not affected by biotin supplementation; however, the arterial concentration of $\mathrm{O}_{2}$ and haemoglobin tended to increase when supplemental biotin was fed $(P=0.11$ and $P=0.14$, respectively).

Supplemental biotin increased $(P<0.10)$ net PDV release of ammonia (Table 5), but the net flux of other metabolites across the PDV was not affected. Similarly, the
Table 3 Body weight, dry-matter intake (DMI) and milk yield, composition and component yield in lactating dairy cows fed a diet without (control) or with supplemental biotin

\begin{tabular}{lcccc}
\hline \hline & Control & Biotin & s.e. & $P$ \\
\hline Body weight (kg) & 662 & 665 & 26 & 0.904 \\
DMl (kg/day) & 22.3 & 22.1 & 1.5 & 0.901 \\
Milk yield (kg/day) & 29.3 & 29.7 & 2.3 & 0.886 \\
FCM $^{\dagger}(\mathrm{kg} /$ day) & 30.0 & 30.0 & 2.6 & 0.989 \\
Protein content (g/kg) & 34.6 & 34.6 & 0.8 & 0.957 \\
Fat content $(\mathrm{g} / \mathrm{kg})$ & 41.5 & 41.0 & 1.5 & 0.744 \\
Lactose content $(\mathrm{g} / \mathrm{kg})$ & 47.1 & 47.5 & 0.5 & 0.671 \\
Protein output $(\mathrm{g} /$ day) & 1012 & 1027 & 63 & 0.876 \\
Fat output (g/day) & 1219 & 1209 & 110 & 0.922 \\
Lactose output (g/day) & 1388 & 1412 & 123 & 0.863 \\
\hline \hline
\end{tabular}

${ }^{\dagger}$ Fat-corrected $(40 \mathrm{~g} / \mathrm{kg})$ milk yield.

net flux of metabolites measured across the liver and total splanchnic tissues, and the fractional removal of lactate, alanine and ammonia by the liver, were not affected by biotin supplementation There was no effect of supplemental biotin on net liver release of glucose, or removal of the glucose precursors alanine and lactate. Arterial concentrations and net fluxes of VFA across the PDV, liver and total splanchnic tissues (Table 6) and the fractional net extraction of VFA by the liver (Table 7) were not affected by supplemental biotin, although there was a numerical increase in net liver removal of $\mathrm{i}$-valerate $(P=0.20)$ when biotin was added to the diet.

Table 4 Blood and plasma flows and packed cell volume in lactating dairy cows fed a diet without (control) or with supplemental biotin

\begin{tabular}{lcccc}
\hline \hline & Control & Biotin & s.e. & $P$ \\
\hline Blood flow (I/h) & & & & \\
$\quad$ Portal & 2037 & 2004 & 164 & 0.883 \\
Liver & 2611 & 2531 & 125 & 0.655 \\
$\quad$ Hepatic artery & 579 & 544 & 337 & 0.934 \\
Plasma flow (I/h) & & & & \\
$\quad$ Portal & 1469 & 1426 & 132 & 0.804 \\
Liver & 1879 & 1792 & 70 & 0.553 \\
Hepatic artery & 395 & 387 & 211 & 0.961 \\
Packed cell volume (\%) ${ }^{\dagger}$ & 28.3 & 28.7 & 1.4 & 0.588 \\
Arterial haemoglobin (g/l) & 94.5 & 98.7 & 4.73 & 0.135 \\
Arterial concentration (mmol/l) & & & & \\
Blood & & & & \\
$\quad$ Alanine & 0.248 & 0.226 & 0.040 & 0.551 \\
$\quad$ Glutamine & 0.210 & 0.215 & 0.015 & 0.843 \\
$\quad$ Glutamate & 0.119 & 0.121 & 0.012 & 0.614 \\
$\quad$ Ammonia & 0.274 & 0.188 & 0.048 & 0.449 \\
$\quad \beta$-Hydroxybutyrate & 0.587 & 0.593 & 0.019 & 0.470 \\
$\quad$ Oxygen & 5.351 & 5.571 & 0.275 & 0.106 \\
$\quad$ Carbon dioxide & 27.169 & 26.935 & 1.190 & 0.753 \\
Plasma & & & & \\
$\quad$ Lactate & 0.473 & 0.472 & 0.079 & 0.995 \\
$\quad$ Glucose & 3.568 & 3.545 & 0.047 & 0.730 \\
\hline \hline
\end{tabular}

${ }^{\dagger}$ Average for arterial and hepatic and portal vein blood. 
Reynolds, Beever, Steinberg and Packington

Table 5 Net splanchnic metabolism and liver extraction of nutrients in lactating dairy cows fed a diet without (control) or with supplemental biotin

\begin{tabular}{|c|c|c|c|c|}
\hline & Control & Biotin & s.e. & $P$ \\
\hline \multicolumn{5}{|c|}{ Portal drained visceral (mmol/h) } \\
\hline \multicolumn{5}{|l|}{ Blood } \\
\hline Alanine & 90 & 78 & 11 & 0.440 \\
\hline Glutamine & 12 & -40 & 51 & 0.535 \\
\hline Glutamate & 11 & 11 & 3 & 0.879 \\
\hline Ammonia & 703 & 945 & 79 & 0.080 \\
\hline$\beta$-Hydroxybutyrate & 265 & 297 & 45 & 0.689 \\
\hline Oxygen & -3672 & -3673 & 303 & 0.995 \\
\hline Carbon dioxide & 1828 & 1697 & 533 & 0.892 \\
\hline \multicolumn{5}{|l|}{ Plasma } \\
\hline Lactate & 172 & 177 & 18 & 0.699 \\
\hline Glucose & 27 & 11 & 18 & 0.565 \\
\hline \multicolumn{5}{|l|}{ Liver (mmol/h) } \\
\hline \multicolumn{5}{|l|}{ Blood } \\
\hline Alanine & -22 & -36 & 8 & 0.374 \\
\hline Glutamine & -45 & 30 & 55 & 0.529 \\
\hline Glutamate & 39 & 25 & 4 & 0.177 \\
\hline Ammonia & -821 & -943 & 47 & 0.341 \\
\hline$\beta$-Hydroxybutyrate & 401 & 388 & 147 & 0.692 \\
\hline Oxygen & -3941 & -3842 & 708 & 0.873 \\
\hline Carbon dioxide & 1449 & 1567 & 405 & 0.642 \\
\hline \multicolumn{5}{|l|}{ Plasma } \\
\hline Lactate & -107 & -83 & 34 & 0.713 \\
\hline Glucose & 694 & 679 & 62 & 0.736 \\
\hline \multicolumn{5}{|l|}{ Total splanchnic (mmol/h) } \\
\hline \multicolumn{5}{|l|}{ Blood } \\
\hline Alanine & 65 & 46 & 13 & 0.515 \\
\hline Glutamine & -31 & -12 & 26 & 0.720 \\
\hline Glutamate & 50 & 36 & 6 & 0.211 \\
\hline Ammonia & -114 & -4 & 43 & 0.345 \\
\hline$\beta$-Hydroxybutyrate & 668 & 676 & 71 & 0.886 \\
\hline Oxygen & -7572 & -7493 & 613 & 0.899 \\
\hline Carbon dioxide & 3209 & 3419 & 261 & 0.693 \\
\hline \multicolumn{5}{|l|}{ Plasma } \\
\hline Lactate & 64 & 95 & 30 & 0.617 \\
\hline Glucose & 718 & 692 & 51 & 0.707 \\
\hline \multicolumn{5}{|c|}{ Net liver extraction (\% of total supply) } \\
\hline Lactate & 10.1 & 7.9 & 2.7 & 0.691 \\
\hline Alanine & 3.5 & 4.6 & 1.6 & 0.734 \\
\hline Ammonia & 58.6 & 68.9 & 5.0 & 0.369 \\
\hline \multicolumn{5}{|c|}{ Net liver removal (\% of portal-drained visceral release) } \\
\hline Lactate & 62.0 & 46.5 & 18.2 & 0.676 \\
\hline Alanine & 27.4 & 43.1 & 15.8 & 0.631 \\
\hline Ammonia & 118.2 & 99.8 & 7.0 & 0.338 \\
\hline
\end{tabular}

\section{Discussion}

Milk yield

The present study was designed to determine effects of biotin on nutrient absorption and liver metabolism, and not feed intake and milk production. Therefore, DM offered was restricted to just below ad libitum and not altered over the course of the study to reduce variation in nutrient absorption and metabolism by splanchnic tissues attributable to DMI. In dairy cows fed ad libitum, supplemental
Table 6 Arterial concentration and net flux of blood volatile fatty acids in lactating dairy cows fed a diet without (control) or with supplemental biotin

\begin{tabular}{|c|c|c|c|c|}
\hline & Control & Biotin & s.e. & $P$ \\
\hline \multicolumn{5}{|c|}{ Arterial concentration $(\mathrm{mmol} / \mathrm{l})$} \\
\hline Acetate & 2.432 & 2.591 & 0.067 & 0.367 \\
\hline Propionate & 0.062 & 0.06 & 0.005 & 0.794 \\
\hline n-Butyrate & 0.033 & 0.03 & 0.004 & 0.594 \\
\hline i-Butyrate & 0.005 & 0.006 & 0.001 & 0.557 \\
\hline i-Valerate & 0.008 & 0.008 & 0.001 & 0.854 \\
\hline n-Valerate & 0.002 & 0.003 & 0.001 & 0.317 \\
\hline \multicolumn{5}{|c|}{ Portal-drained visceral flux (mmol/h) } \\
\hline Acetate & 3074 & 3711 & 468 & 0.399 \\
\hline Propionate & 903 & 963 & 118 & 0.632 \\
\hline n-Butyrate & 206 & 218 & 29 & 0.839 \\
\hline i-Butyrate & 24 & 23 & 3 & 0.702 \\
\hline i-Valerate & 45 & 51 & 3 & 0.444 \\
\hline $\mathrm{n}$-Valerate & 37 & 42 & 5 & 0.678 \\
\hline \multicolumn{5}{|c|}{ Liver flux, $\mathrm{mmol} / \mathrm{h}$} \\
\hline Acetate & 1995 & 1634 & 930 & 0.567 \\
\hline Propionate & -831 & -885 & 124 & 0.657 \\
\hline n-Butyrate & -144 & -160 & 39 & 0.737 \\
\hline i-Butyrate & -21 & -20 & 5 & 0.609 \\
\hline i-Valerate & -39 & -47 & 5 & 0.194 \\
\hline $\mathrm{n}$-Valerate & -38 & -42 & 5 & 0.683 \\
\hline \multicolumn{5}{|c|}{ Total splanchnic flux (mmol/h) } \\
\hline Acetate & 5062 & 5180 & 741 & 0.983 \\
\hline Propionate & 72 & 77 & 14 & 0.836 \\
\hline n-Butyrate & 66 & 52 & 16 & 0.506 \\
\hline i-Butyrate & 3 & 3 & 3 & 0.933 \\
\hline i-Valerate & 7 & 3 & 3 & 0.502 \\
\hline $\mathrm{n}$-Valerate & -1 & -1 & 1 & 0.665 \\
\hline
\end{tabular}

biotin has typically increased milk yield (Bonomi et al., 1996; Midla et al., 1998; Zimmerly and Weiss, 2001; Bergsten et al., 2003; Majee et al., 2003) but the effect has not been observed in every study reported (Fitzgerald et al., 2000; Rosendo et al., 2004). In the present study, the lack of a milk yield response to supplemental biotin may have been due to the restricted DMI of the cows, or the length

Table 7 Net liver extraction of blood VFA as a percentage of net PDV release or total blood supply in lactating dairy cows fed a diet without (control) and with supplemental biotin

\begin{tabular}{|c|c|c|c|c|}
\hline & Control & Biotin & s.e. & $P$ \\
\hline \multicolumn{5}{|c|}{ Net liver removal ( $\%$ of total blood supply) } \\
\hline Propionate & 77.3 & 79.1 & 2.9 & 0.545 \\
\hline n-Butyrate & 48.3 & 54.2 & 10.4 & 0.335 \\
\hline i-Butyrate & 57.1 & 52.2 & 13.7 & 0.403 \\
\hline i-Valerate & 60.3 & 66.3 & 9.0 & 0.335 \\
\hline $\mathrm{n}$-Valerate & 88.4 & 87.0 & 1.2 & 0.359 \\
\hline \multicolumn{5}{|c|}{ Net liver removal (\% of portal-drained visceral release) } \\
\hline Propionate & 91.4 & 91.6 & 2.2 & 0.950 \\
\hline n-Butyrate & 66.9 & 73.1 & 10.7 & 0.484 \\
\hline i-Butyrate & 87.7 & 85.4 & 14.8 & 0.775 \\
\hline i-Valerate & 85.2 & 92.4 & 7.7 & 0.466 \\
\hline $\mathrm{n}$-Valerate & 103.3 & 101.7 & 1.5 & 0.614 \\
\hline
\end{tabular}


of supplementation (14 days) may have been too short to allow for effects on milk yield. However, in a recent study Ferreira (2006) measured an increase in milk yield within 2 days of the start of biotin supplementation in higher yielding (43 kg/day) cows in early lactation, but no effect of biotin on milk yield in lower yielding $(23 \mathrm{~kg} /$ day) cows in late lactation.

\section{Glucose metabolism}

There was no effect of feeding $20 \mathrm{mg} /$ day supplemental biotin for 2 weeks on net liver release or plasma concentrations of glucose in these cows. In the present study there was no effect of supplemental biotin on milk or milk lactose yield, thus no apparent effect on glucose requirement. It is unlikely that in these cows near or well past peak diet intake that the supply of glucose precursors was limiting. Therefore, it is unlikely that liver glucose synthesis was limiting milk production. A positive effect of biotin on glucose synthesis in the liver in non-ruminants may be a consequence of the repletion of a biotin deficiency limiting the activity of gluconeogenic enzymes, rather than a promotion of carboxylase activity per se (Bender, 1999).

Reasons for the increase in jugular vein plasma glucose concentration reported by Bonomi et al. (1996) and Rosendo et al. (2004) are not certain. An increased supply of oxaloacetate via a stimulation of carboxylase activity in the liver would only be used for glucose synthesis if the additional oxaloacetate was required (Reynolds, 1995). The lack of an effect of supplemental biotin on liver lactate, alanine or $\beta$-hydroxybutyrate metabolism suggests there was little change in the utilisation of pyruvate, as the net flux of these metabolites across the bovine liver are sensitive indicators of pyruvate and redox status (Reynolds, 1995).

\section{Nitrogen metabolism}

Effects of biotin supplementation on ammonia absorption by the PDV were not expected. The magnitude of the increase was much greater than the amount of nitrogen (N) in biotin fed, and was accompanied by a numerical increase in liver ammonia removal. The increase in ammonia absorption when biotin was fed may be attributable to changes in PDV tissue metabolism, fermentation in the rumen or hindgut, or an increase in the cycling of urea $\mathrm{N}$ to the gut lumen (via saliva or direct transfer from blood). Urea transfer to the rumen is influenced by a number of factors including fermentable energy and urease activity. Biotin supplementation may have improved microbial energy supply and growth, but this would be expected to decrease net PDV absorption of ammonia as observed when starch was infused into the rumen or abomasum of lactating dairy cows (Reynolds et al., 1998).

\section{Volatile fatty acid metabolism}

Previous studies in vitro have demonstrated positive effects of biotin on microbial degradation of cellulose, which would cause a relative increase in VFA production (Milligan et al., 1967; Baldwin and Allison, 1983). However, apart from numerical increases in net acetate, i-valerate and total VFA release by the PDV, there was no evidence that feeding biotin altered rumen or post-rumen fermentation. Similarly, there was no effect of feeding biotin on rumen VFA proportions (Zimmerly and Weiss, 2001) or total tract fibre digestion (Majee et al., 2003).

\section{Conclusions}

Feeding supplemental biotin for 2 weeks to lactating dairy cows had no measurable effect on milk production, net glucose production by the liver, or circulating glucose concentrations in blood plasma. This indicates that biotin status in these cows did not limit liver pyruvate and proprionyl-CoA carboxylase function, or that the supply of glucose precursors was not limiting liver glucose production. Surprisingly, feeding $20 \mathrm{mg}$ biotin per day increased net absorption of ammonia $\mathrm{N}$ by the PDV. Reasons for these responses are not certain, but a numerical increase in acetate absorption suggests an alteration in rumen fermentation occurred. The results of the present study do not support the hypothesis that feeding supplemental biotin to lactating dairy cows increases glucose production by the liver.

\section{Acknowledgements}

The laboratory support of Drs. Berit Lupoli and Patricia Aikman are gratefully acknowledged, as are the dedicated support of Dave Humphries and the technical staff of the CEDAR Metabolism Unit in the daily management and care of cows and conduct of this study. The analysis of milk samples by staff of the Faculty Analytical Laboratory is also greatly appreciated.

\section{References}

Baldwin RL and Allison MJ 1983. Rumen metabolism. Journal of Animal Science 57, (suppl. 2) 461-477.

Bender DA 1999. Optimum nutrition: thiamin, biotin and pantothenate. Proceedings of the Nutrition Society 58, 427-433.

Benson JA, Reynolds CK, Aikman PC, Lupoli B and Beever DE 2002. Effects of abomasal long chain fatty acid infusion on splanchnic nutrient metabolism in lactating dairy cows. Journal of Dairy Science 85, 1804-1814.

Bergsten C, Greenough PR, Gay JM, Seymour WM and Gay CC 2003. Effects of biotin supplementation on performance and claw lesions on a commercial dairy farm. Journal of Dairy Science 86, 3953-3962.

Bonomi A, Quarantelli A, Sabbioni A and Superchi P 1996. L'intergrazione della razioni per le bovine da latte con biotina in forma rumino-protetta. Effetti sull'efficienza produttiva e riproduttiva. La Rivista di Scienza dell'Alimentazione 25, 49-68.

Church DC 1979. Digestive physiology and nutrition of ruminants, vol. 2 nutrition. 0 \& B Books, Inc., Corvallis, OR, USA.

Comben N, Clark RJ and Sutherland DJB 1984. Clinical observations on the response of equine hoof defects to dietary supplementation with biotin. Veterinary Record 115, 642-645.

Ferreira G 2006. Effect of biotin supplementation on the metabolism of lactating dairy cows. Ph.D. dissertation, The Ohio State University, Columbus, Ohio.

Fitzgerald T, Norton BW, Elliott R, Podlich H and Svendsen OL 2000. The influence of long-term supplementation with biotin on the prevention of lameness in pasture fed dairy cows. Journal of Dairy Science 83, 338-344.

Girard CL 1998. The B-complex vitamins for dairy cows: a new approach. Canadian Journal of Animal Science 78, SS71-90. 
Hedges J, Blowey RW, Packington AJ, O'Callaghan CJ and Green LE 2001. A longitudinal field trial of the effect of biotin on lameness in dairy cows. Journal of Dairy Science 84, 1969-1975.

Huntington GB, Reynolds CK and Stroud B 1989. Techniques for measuring blood flow in splanchnic tissues of cattle. Journal of Dairy Science 72, 1583-1595.

Majee DN, Schwabb EC, Bertics SJ, Seymour WM and Shaver RD 2003. Lactation performance by dairy cows fed supplemental biotin and B-vitamin blend. Journal of Dairy Science 86, 2106-2112.

Midla LT, Hoblet KH, Weiss WP and Moeschberger ML 1998. Supplemental dietary biotin for prevention of lesions associated with aseptic subclinical laminitis (pododermatitis aseptica diffusa) in primiparous cows. American Journal of Veterinary Research 59, 733-738.

Milligan LP, Asplund JM and Robblee AR 1967. In vitro studies on the role of biotin in the metabolism of rumen microorganisms. Canadian Journal of Animal Science 47, 57-64.

Reynolds CK 1995. Quantitative aspects of liver metabolism in ruminants. In Ruminant physiology: digestion, metabolism, growth and reproduction. Proceedings of the eighth international symposium on ruminant physiology (eds Wv Engelhardt, S Leonhard-Marek, G Breves and D Giesecke), pp. 351372, Ferdinand Enke Verlag, Stuttgart, Germany.

Reynolds CK, Aikman PC, Lupoli B, Humphries DJ and Beever DE 2003. Splanchnic metabolism of dairy cows during the transition from late gestation through early lactation. Journal of Dairy Science 86, 1201-1217.

Reynolds CK, Humphries DJ, Cammell SB, Benson JA, Sutton JD and Beever DE 1998. Effects of abomasal wheat starch infusion on splanchnic metabolism and energy balance of lactating dairy cows. In Energy metabolism of farm animals, proceedings of the 14th symposium on energy metabolism (ed. KJ McCracken, EF Unsworth and ARG Wylie), pp. 39-42, CAB International, Wallingford, UK.

Reynolds CK, Lupoli B, Aikman PC, Benson JA, Humphries DJ, Crompton LA, France J, Beever DE and MacRae JC 2000. Effects of diet protein level and abomasal amino acid infusions on splanchnic metabolism in lactating dairy cows. Journal of Dairy Science 83, (suppl. 1) 299.

Reynolds CK, Lupoli B, Aikman PC, Humphries DJ, Crompton LA, Sutton JD, France J, Beever DE and MacRae JC 1999. Effects of abomasal casein or essential amino acid infusions on splanchnic metabolism in lactating dairy cows. Journal of Animal Science 77, (suppl. 1) 266.

Rosendo O, Staples CR, McDowell LR, McMahon R, Badinga L, Martin FG, Shearer JF, Seymour WM and Wilkinson NS 2004. Effects of biotin supplementation on peripartum performance and metabolites of Holstein cows. Journal of Dairy Science 87, 2535-2545.

Statistical Analysis Systems Institute 2006. Version 9.1.3. SAS Institute Inc., Cary, NC, USA.

Templeman RJ 2004. Experimental design and statistical methods for classical and bioequivalence hypothesis testing with an application to dairy nutrition studies. Journal of Animal Science 82, (E. suppl.) E162-E172.

Webb NG, Penny RHC and Johnston AM 1984. Effect of dietary supplement of biotin on pig hoof horn strength and hardness. Veterinary Record 114, 185-189.

Zimmerly CA and Weiss WP 2001. Effects of supplemental dietary biotin on performance of Holstein cows during early lactation. Journal of Dairy Science $84,498-506$. 